\title{
Appendix A \\ "The Will to Believe" and James's "Deontological Streak"
}

After publishing the preceding study of James's classic lecture under the title William James on the Courage to Believe, I was grateful to the reviewers who dealt with it, for the most part, with such kindness. This was especially so because I had over the years developed such an admiring fondness for that lecture.

But it came as no surprise that even the more receptive reviewers did not conceal that they had honest reservations on one point or another. ${ }^{1}$ Those reservations, significantly, instead of flying like arrows aimed at haphazard and landing all over the target, zeroed in for the most part on several points of convergence. Was I, my critics asked first of all, correct in speaking of James's ethics as revealing a "deontological streak"? And if so, did that deontological lean persuade James, perhaps only half-aware, to justify the precursive influence of "will" on the formation of our weltanschaulich "over-beliefs" in a way that turns out to have been far more voluntaristic than genuinely "pragmatic"? In the light of that last objection, finally, have I, when all is said, succeeded only in exposing (in both senses of the term) James's defense of belief as viciously circular?

In this essay I mean to confine myself to the questions centering about the existence of that "deontological streak." But because several of the issues already men-

An earlier version of this essay appeared in Transactions of the Charles S. Peirce Society, 28 (1992), 809-31. 
tioned, including that of deontology, have since been given a keener edge by the publication of James C. S. Wernham's study James's Will-to-Believe Doctrine: A Heretical View, ${ }^{2}$ a few introductory observations on Wernham's book are in order. I shall restrict myself to the issues which figure into the discussion of James' $s$ "deontological streak."

\section{A Difference in Purposes}

And, first, it should be noted from the outset that Wernham's object in writing his book was markedly different from mine. I made no secret of my twin convictions that, first, James seemed to be making an important cluster of philosophical points in his Will to Believe and in the whole series of "popular" lectures which form its "setting"; but that, second, he did not always succeed in making those points as cogently as they deserve to be made. I set myself the task, accordingly, of striving to sift out what was valid in James's intentions, and then improving his argument until it was cogent enough to drive home the point he had hoped to make. Wernham, for his part, is content (as he has every right to be, of course) to examine James's argumentation exactly as it stands, then decide on what conclusion (or conclusions) that argumentation gives him the right to draw.

It is not entirely clear that Wernham clearly grasped this difference between our approaches: he contends, for instance, that James's logic authorizes him to conclude only that we are "better off" if we choose to "bet" on God's existence. But "betting," Wernham argues, is not necessarily the same as "believing" that God exists. This is the context in which he makes his only allusion to my study (p. 119n12): he appears to class me with those (like John Hick) who look on betting as necessarily an unserious business, and therefore unworthy of consideration when it comes to taking a stand on the religious question. 
A bet, Wernham rightly points out, can sometimes be a deeply serious undertaking.

A closer reading might have shown him that on the page he cites I was arguing precisely against John Hick's contention that James was recommending we bet on God's existence, and that he could have meant that term "wager" only in the relatively frivolous, "sporting life" understanding of the term. Far from disagreeing with Wernham, I hoped to make it clear that there were unquestionably elements of the "serious" kind of bet in what James was recommending. The Jamesian universe, I wrote in concluding my study, is "earnest infinitely" and "plays us down to our bottom card. That bottom card, to win, must show naked manly courage." ${ }^{\prime \prime}$ (p. 121). Surely that is betting language, but (pace Hick) the language of a profoundly serious bet!

But does this mean that I think James would have been happy at being told that his argumentation authorized us to "bet" on God's existence, but not to "believe" that $\mathrm{He}$ existed? Not in the least. For it may be true, as Wernham reasons, that one can bet on a horse without necessarily believing that the horse will win (pp. 103-105), but I cannot accept that James's commendation that we choose to "believe" in God's existence was meant to be of the same quality, weight, and seriousness as the advice of a tout, however soberly given, that we wager on Number Six in the Third. Had James read Wernham's book, and been convinced by it, I imagine him wanting to go back to his own essay in hopes of beefing up its reasoning so that it wound up warranting the stronger conclusion he had originally hoped his readers would feel entitled to draw.

To repeat, though, Wernham's conclusion seems perfectly consonant with the intention commanding his essay and the method entailed by it: that of carefully analyzing what James's argument actually warrants as its conclusion, and permitting him no stronger a conclusion than his argument genuinely warrants. This is one valuable task the philosopher can choose to take on, once he has become aware of the gaps and difficulties in James's 
essay. I, on the other hand, chose to take on a different task, one more like the one I imagine James might have taken on: that of closing the gaps and ironing out the difficulties, out of the conviction that the essay's original conclusion was sound enough and important enough to merit salvaging.

\section{The Precursive Influence of the "Passional"}

Whether or not it should be viewed as a gap or difficulty, my own study of James's essay convinced me of a feature which few if any defenders of James seemed to have noticed: I have called it the "precursive influence of the passional." It does not appear that Wernham himself has noticed this feature or dealt with the devastating objection it could be made to represent to James's entire argument. I have to think it quite remarkable that none of the reviewers chose to challenge the central claim which, I had thought, was the most revolutionary feature in my interpretation. Briefly put: I found that James was arguing not only that the "passional side" of our nature did intervene in the formation of "belief" after our intellectual survey of the evidence had come up dry, so to speak, but also that it presided (and legitimately) before and during, influencing and even commanding, that intellectual survey.

Patrick Dooley, however, objected to that claim (p. 575), but from an unexpected quarter: he wondered why I considered it in any way "news." $\mathrm{He}$ and (so he claimed) three authors before him had stressed that for James, both early and late, "passional demands tremendously influence both our beliefs and overbeliefs." "Whatever justice there may be in Dooley's contention, it seemed clear that the message he and his colleagues had striven to convey had not gotten through to a spate of writers-Kennedy, Hick, Davis, Muyskens, Hare, and Madden (in an earlier article)-who had focused their studies precisely on this famous lecture, and, whether 
attacking or defending James, wrote as though our passional side might intervene only after an intellectual survey of the evidence had left us still in doubt. Besides, half reluctantly admitting the precursive influence of the passional may be one thing, facing it squarely and satisfactorily resolving the difficulties it entails is quite another. And that, pace Dooley, I found nobody doingnot, at least, to my satisfaction.

But Dooley's ostensible agreement with my contention soon turns out to veil a deeper disagreement; he finds my way of interpreting the force of this precursive influence profoundly unpalatable. For he sees, and rightly, that my interpretation threatens to elide, indeed, to positively exclude, the step of verifying the truth of our over-arching "beliefs" by means of any "pragmatic check" (p. 574). Dooley's fear is well-grounded, for my claim comes down precisely to this: if my interpretation of James's "will" to believe is correct, then when it comes to our truly weltanschaulich beliefs, all such pragmatic verification can have only the remotest relevance, so that appeals to such verification come to little more than a charade.

For, as James describes it, the influence which the passional side of our nature exerts on our intellectual survey of the evidence is, and indeed should be, sufficiently powerful to guarantee that, in deciding weltanschaulich questions like theism vs. atheism, freedom vs. determinism, pluralism $v s$. monism, we shall come to a truly sane and healthy conclusion. Now, this view of how the passional intervenes pulls the teeth out of any pragmatic verification of theism; for what can "verification" genuinely mean when the will has foreordained the conclusion that our observation and reasoning must come to?

But this certainly seems, at first glance anyway, to indict James of holding a voluntarist position in which the responsible weighing of evidence on either side of any "belief" question no longer counts for anything: that, in a nutshell, is the difficulty regarded more from the epistemological point of view. Another way of putting the matter, though, is this: placing the passional side of our 
nature so much in control of the formation of our beliefs would seem to make James guilty of the charge so often leveled at him: the charge of "wishful thinking." This is the same difficulty as we saw above, but expressed, now, in more ethical terms: James is giving us a license to believe whatever we find it attractive to believe.

I am convinced that whichever framing of this difficulty the pro-Jamesian defense attorney chooses to deal with, he will eventually be compelled to make an appeal to the "deontological streak" in James's moral-religious thinking. Permit me, though, to leave the epistemological side of the difficulty for treatment on some future occasion; allow me to restrict myself here to showing how it is important, for answering the "wishful thinking" charge, to recognize the existence of a "deontological streak" in James's ethical thinking.

\section{The “NON-PRECURSIVE” INTERPRETATION OF JAMES}

It is not difficult to understand why a number of critics have accused James, in "The Will to Believe," of defending our right to "wishful thinking." Wernham's study illustrates, albeit unintentionally, the conception of James's argument which lays it open to this charge, even if one assumes (as most writers do) that the passional side of our natures does not exert its influence precursively. On that assumption, James would imagine our thinking about the theistic hypothesis (to take that example) as normally running this way: we start by making as dispassionate a survey as is humanly possible of the evidence and reasons on either side of the issue; suppose, now, that after this intellectual evaluation both negative and positive conclusions make an equal appeal to our intellects: the issue, in other words, is undecidable on intellectual grounds. Suppose, further, that we cannot indefinitely postpone making some decision; we must decide one way or the other. In such a case, this school of writers say, it is legitimate to allow the "passional" or 
"willing" side of our nature to decide the issue on the basis of which alternative appears more desirable than its competitor.

This seems to be the scenario Wernham is implicitly following when he writes (p. 103) that it would be foolish "not to gamble on theism . . . because an 'immediate reward' . . . attaches to the act itself of betting on that side. That reward," Wernham goes on to explain, "James called 'the strenuous mood.' The capacity for it could be activated, he thought, by postulating theism, not just by believing it; and the strenuous life was the best life whether or not it was the right life."5

\section{The Entry of "Wishful Thinking"}

Now, there are several features of Wernham's case here which I must temporarily ignore in order to go straight to the point $I$ intend to deal with. But the fact that I pass over them without demurral should not imply that I agree, for instance, that James seriously intended to argue only that we may "gamble" on theism, or that activating the "strenuous mood" requires only that we "postulate," not that we "believe" in, God's existence. But my differences with Wernham on both those points undoubtedly derive from the basic difference between our intentions, as I tried to explain above. The point that interests me here, though, concerns Wernham's appreciation of what James means by the "strenuous mood," and how he sees it fitting into James's argument for the will to believe.

From the language used above, Wernham looks on living in the "strenuous mood" as the "immediate reward" (he borrows the term from Ducasse) "attaching to the act itself of betting on that [i.e., the theistic] side." This language seems to imply that for the willing or passional side of our nature to opt for theism, we must be attracted by something in the nature of a "reward." This, in turn, is consonant with Wernham's position that the kind of choice James is summoning us to make is a "prudential" 
one, by which Wernham means that we choose that which will make us "better off" (pp. 15-16, 20). Wernham has, in short, made the "strenuous mood" function as a motivating object in what he calls the "prudential" type of decision. Further, by making life in the "strenuous mood" more desirable, he has made it the kind of life we would naturally "wish for"- and by the same token made "wishful thinking" the crucial motor in our decision to believe.

\section{The "Genial" and "Strenuous" Moral Moods}

I have, in my essay, consistently used the term "eudaemonistic" for what Wernham calls "prudential," and I see no difficulty in accepting his specification that such a prudential/eudaemonistic decision always turns on what promises to make us "happier" or "better off." Both of us, moreover, set the prudential type of decision in contradistinction to what Wernham calls the "moral," and what I prefer to call the "deontological," type of decision. And we would both concur, unless I mistake him, in characterizing this latter sort of decision as turning on what we perceive as "obligatory," irrespective of whether doing it promises to make us "better off" or not.

Now, it is common knowledge that James divides the human universe into two main classes or ethical types. Those in the first and perhaps the more common type tend as a rule to make their ethical choices in eudaemonistic or prudential terms, looking to what will leave them "better off": these James labels as living in the "genial" or "easy-going" moral mood. The other, rarer type is more inclined to make certain of its ethical choices, at least, in what I have called deontological and Wernham calls "moral" terms: they are far more sensitive than their easy-going counterparts to the inspirational power of the honorable, the noble, the heroic, even (and perhaps especially) when the summons to a course of action makes self-sacrificial demands on them. These are the tenants of what James calls the "strenuous" moral mood. 
Now, James would undoubtedly admit that most of the routine decisions of life can legitimately be made in accord with the "genial" calculus of what leaves us "better off." But he also insists that there are moments and situations in life in which our human mettle is tested by our capacity to put "better off" considerations in a remote second place, and decide in accord with the canons native to the "strenuous" moral mood. To express this in the terms I used above, eudaemonism is an ethic which will serve quite adequately for our fair weather decisions; James would have no difficulty admitting this. But he was also convinced that life can turn stormy and suddenly make austere demands upon our capacity for the heroic; then, he insisted, the genuinely moral person must be able to shift ethical gears and respond to challenges in the "strenuous" moral mood. Now, this is the type of ethical attitude I tried to characterize when I spoke of James himself as possessing a "deontological streak."

\section{The "Strenuous" or "Serious" Moral Mood}

Two of my critics raised direct questions about that interpretation; Tilley (p. 755) found my "claim to have uncovered" such a streak "debatable," while McDermott complained that one would never guess from what I had written that James was a "consequentialist" in ethics. No wonder, then, he found my use of the term deontologism "unfortunate": surely, he hoped, I did not mean to "equate James's position with the bleak, situation-free deontological ethics of Kant and H. D. Ross"? In analyzing James's use of the "friendship" metaphor, moreover, I had suggested that the term "willingness" to meet the other half-way was more appropriate than "will," but the dynamics of that metaphor did not strike McDermott as "in any way deontological" (p. 190). That second observation is at least half-right, but it should be clear from my text that James's appeal to the friendship metaphor warranted only a limited conclusion: the deontological em- 
phasis, I argued, emerges far more appropriately from the "Alpinist" and "robber-band" metaphors James also brings to bear. I cannot resist remarking here, however, that analysis of the stages in a growing friendship might well reveal a deontological side to that process and that James, I think, would have been sympathetic to that suggestion.

In any event, I carefully forbore from characterizing James's ethic as purely deontological; the expression I used was that his ethic had a "deontological streak." Hence, I may waive the necessity of comparing him at any length with either Kant or Ross: those gentlemen I leave to take care of themselves. But I am questioning the adequacy of McDermott's characterization of James's ethics as "consequentialist," in any pure sense of that term. Madden's remarks (in Works VI, pp. xxxi-Xxxii) provide a lead toward my contention: "James's moral philosophy," he writes, "is clearly teleological and utilitarian," but he "clearly diverges from classical utilitarians" by transforming their "pleasure" into the broader "satisfaction of needs, wants, and desires." But, Madden goes on to say, "In addition, there is an active and volitional, even heroic, dimension to value experiences to which utilitarianism, James thought, does not do justice." $\mathrm{He}$ had no use for a world in which "there was no genuine evil to overcome and hence no heroic gestures and sacrifices needed. He preached the gospel of Thomas Carlyle and Rudyard Kipling when the mood was on," despite the danger that preaching involved, of embracing the "notion that evil can be considered instrumentally good."

That was not the only paradox James was flirting with, but let it pass for the moment; it is Madden's recognition of the "heroic" motif in James's ethics that is worth dwelling on. One of James's clearest statements of his difference from classic utilitarianism occurs in the early essay "The Moral Philosopher and the Moral Life" (pp. 142-45) which James himself, Madden avers, considered the "most important one" in the volume containing "The Will to Believe." But the "addition" it brings to his already 
modified form of utilitarianism goes somewhat further, I suggest, than Madden allows: it shows that James perceived that all "eudaemonisms," all forms of "consequentialism," were inadequate as ethical theories unless they admitted the balancing complement of the "deontological streak" I claimed to find in him.

He commends the "Benthams, Mills, and the Bains" on their lasting service in tracing so many of our ethical ideals to their "association with acts of simple bodily pleasure and reliefs from pain." Their form of eudaemonism, accordingly, James would accord a wide field of applicability, as I pointed out earlier. But, James goes on to say, "it is surely impossible to explain all our sentiments and preferences in this simple way." The sentiments he refers to include a "vast number of our moral perceptions" which "deal with directly felt fitnesses between things, and often fly in the teeth of all the prepossessions of habit and presumptions of utility." Consider, for example, the "sense for abstract justice which some people have" or the "feeling of the inward dignity of certain spiritual attitudes, as peace, serenity, simplicity, veracity." Such value judgments are, he contends,

-quite inexplicable except by an innate preference of the more ideal attitude for its own pure sake. The nobler thing tastes better, and that is all that we can say. 'Experience' of consequences may truly teach us what things are wicked, but what have consequences to do with what is mean and vulgar?

But the robust sense in which James is using terms like "taste," "mean," and "vulgar" becomes clear from the second of two illustrative examples he gives. What if

the hypothesis were offered us of a world in which Messr. Fourier's and Bellamy's and Morris's utopias should all be outdone, and millions kept permanently happy on the one simple condition that a certain lost soul on the faroff edge of things should lead a life of lonely torture, what except a specifical and independent sort of emotion can it be which would make us immediately feel, even though 
an impulse arose within us to clutch at the happiness so offered, how hideous a thing would be its enjoyment when deliberately accepted as the fruit of such a bargain?

This passage, I submit, illustrates perfectly what I meant by James's "deontological streak." He does not deny that experience of "consequences" can and does in numerous cases serve as our criterion for what is ethically good or bad; but he insists that there are other cases where a different criterion must be acknowledged-a criterion which not only complements, but would actually correct the kind of decision we might otherwise make on purely consequentialist grounds.

James goes on to "applaud the intuitionist school" (the Kantians, presumably) for having perceived this side of the matter. But his true forebears, I still suggest, lie further back, in thinkers like Socrates and Plato, who saw that there were cases in life when we need to apply such categories as James here appeals to: the "noble," the "ideal," the "inward dignity" of certain acts and attitudes for their own "pure sake." But all such appeals, I suggest, invoke a deontological intuition, an insight into simple "oughtness."

This side of James's ethics never effaces the "teleological" (what I termed "eudaemonist") side, any more than Plato's "deontological streak" effaced his own basic eudaemonism. In both thinkers, rather, it complements, and on occasion corrects, the force that eudaemonistic criteria would otherwise exert too unilaterally on the basis of foreseen desirable consequences.

In my essay (pp. 101-104), I presented a number of examples instancing the Jamesian language of deonto$\operatorname{logism} ;^{6}$ he talks of owing "allegiance" to a "Spirit in things . . . , for whose sake we must keep up the serious mood," of a "mysteriousness" in reality to which we ascribe "the right to claim from us" the mood of "seriousness, ... the willingness to live with energy, though energy bring pain"; he speaks of God as the only "Infinite Claimant" who can adequately ground the sense of 
"ought" and "obligation" the strenuous mood imports and exacts from us. For with God in the cosmic picture the "more imperative ideals . . . speak with an altogether new objectivity and significance, . . . utter the penetrating, shattering, challenging note of appeal," the appeal, even, "joyously [to] face tragedy for an infinite demander's sake."

Most of the texts above, though not all, come from "The Moral Philosopher and the Moral Life," that "popular lecture" which I take to be the close companion of "The Will to Believe." Texts like these could be multiplied; but even these few indicate why I cannot agree with Madden's characterization of that essay (Works VI, p. xxx) as a "classic example of a teleological system as opposed to a deontological one" (emphasis added). Teleological it is, yes, or, as I would prefer to term it, eudaemonist (for surely both eudaemonism and deontologism can adopt teleological form), ${ }^{7}$ but a eudaemonist system large and comprehensive enough to accommodate the unmistakable deontological "streak" I speak of: for the Jamesian universe (as another of his popular lectures asks us to believe $)^{8}$ holds out the hope that our acts of "bravery and patience" in the teeth of the most "adverse" kind of life may, despite everything, bear "fruit somewhere in the unseen spiritual world." Our universe, in other words, may sometimes make heroic demands on us, demands whose "consequences" we cannot see as other than simply "tragic"; and yet, James was convinced, our deontological fidelity may be-no, must be-eudaemonistically teleological in the cosmic long run.

Texts like these, accordingly, convey the "taste," or the moral "intuition" if you will, which impelled James, from one end of his career to the other, to prefer the "strenuous" as "more ideal" than the "easy-going" moral mood, and consequently inspired his lofty regard for human "heroism." But they also suggest why his famous "ladder of faith," in its non-logical way, ${ }^{9}$ would naturally run from the high value he placed on life lived heroically in the 
strenuous mood, to his passionate belief that our universe must ultimately be hospitable to that type of moral existence. That kind of "match," after all, between the universe and the human creatures it has brought forth, contains nothing self-contradictory; it might be true, may be, is fit to be true. To this point the faith-ladder is moving in the eudaemonist mood, the mood of the "desirable."

But now his argument shifts into the "imperatives" much more coherent with deontology: it ought to be true, must be true. If eudaemonism were the governing consideration, the last step would issue into a "wish" or "right" to believe; only the injection of deontology can account for James's much more robust conclusion, "It shall be true, at any rate for me." That, I submit, is unmistakably the language of voluntarism, of nothing weaker than a resolute "will" to believe.

This is why I argued that, despite his later vacillations and even demurrals, James was correct in concluding that we "ought," in certain circumstances, exert a positive "will" to believe. But, my argument ran, those circumstances were of the kind which demanded of us a deontologically motivated resolve to live or continue living in the "strenuous" moral mood despite the evil "consequences" such a resolve appeared to entail. For the universe can sometimes require us to believe in what "outstrips the evidence," that some heroic-tragic act we are called upon to perform will, after all, bear fruit "somewhere in the unseen spiritual world." And it is especially in such circumstances that the universe requires that we grit our ethical teeth and "will" to believe, at the same time as it affords us an occasion for the noblest type of moral accomplishment of which humans are capable.

But notice that acts like these must be performed far more out of regard for those "higher, more penetrating ideals" which the Jamesian "intuitionist" advocates than out of any foresight of "rewards" or satisfying "consequences." Indeed, the "preference of the more ideal attitude for its own pure sake" comes far closer to uttering a categorical "let the consequences be damned." For that 
reason, I submit that James would have found it distinctly odd of Wernham to classify living in the strenuous mood as itself a species of "reward" for believing in, or postulating, God's existence. That whole style of thinking seems as intrusively alien to the strenuous mood as it would be to insert a harmonica solo into Beethoven's "Eroica" symphony.

One may feel free to question whether this explanation succeeds in "salvaging" the philosophical truth implicated in what I called James's "most alert" teaching; one may feel equally free to question the solidity of the view I have presented, Jamesian or not. But there is one possible accusation I shall never understand: that (pace John Hick) any such act of spiritual bravery can fairly be mistaken for that pallid child of the "easy-going" moral mood, "wishful thinking."

\section{WERNHAM AND WISHFUL THINKING}

But I submit that even if we were to sanction Wernham's manner of inserting the "strenuous mood" into James's argument, it would lay that argument wide open to the wishful thinking charge. For in the ordinary meaning of the term, wish becomes father to our thought when we are contemplating the prospect of being happier, more comfortable, and satisfied: "better off," in Wernham's phrase. Think of the "strenuous mood" uniquely or primarily in terms of "reward," and the wish for that reward can skew our thinking toward adopting the conclusion which ensures our receiving that reward.

But the universe of the "strenuous mood" is traversed by dangers and evils which generate shattering and even tragic ethical demands: does one naturally and spontaneously think of that as the kind of universe one would "wish" for? Even James, when speaking of the heroic type who would "want" a world of this stern sort of moral reality, is clearly using the word "want" in a more muscular sense than we normally accord to the term "wish." 
This is why I attributed such importance to the "deontological streak" in James's ethic; especially after claiming that the passional side of our natures exercised a precursive influence on our intellectual processes, James's argument sorely needed that relatively disinterested ethical attitude to save the decision for theism from the selfindulgence of wishful thinking.

\section{Deontology in Varieties of Religious EXPERIENCE}

Once it is granted, however, that the deontological streak is prominent in James's earlier "popular lectures," the question arises whether that accent persists through his later works. For it could be true that the deontological motif may be vital to the understanding of his essay on the "will to believe" and still represent an aberrant theme, one not truly "Jamesian" in the most authentic sense. It is undeniable, for example, that the opening sections of Varieties of Religious Experience, written some five years later, ${ }^{10}$ seem to downplay the "volitional" moment in religious conversion, subordinating it to a passive surrender which normally implies giving up one's own will and acquiescing in the will of the unseen higher powers.

Yet even in these pages the religious attitude resembles the "strenuous mood" in several respects: it always imports a "serious state of mind," a certain "gravity." It is "hostile to heavy grumbling and complaint," is "solemn, serious" (pp. 38-39), "accepts the universe" even with its evils, "heartily and altogether." But there are differences as well: it seems to transcend the purely moralistic type of strenuous mood in that the "service of the highest is never felt as a yoke" to be shouldered with cold and heavy heart. There is a tremendous difference, James holds, between the "stoic resignation to necessity" of a Marcus Aurelius and the "passionate happiness" exhibited, for example, by "the Christian saints" (p. 41).

Yet James seems to have revived, momentarily, his old enthusiasm for the strenuous mood in its unreligious reg- 
ister when he wrote: "A life is manly, stoical, moral, or philosophical, we say, in proportion as it is less swayed by paltry personal considerations and more by objective ends that call for energy, even though that energy bring personal loss and pain." His next sentence is typical: "This is the good side of war, in so far as it calls for "volunteers" ": one almost expects him to write "heroes." "Such a man," he says, "is a high-hearted freeman," who "lives on his loftiest, largest plane" and "spurns the pinched and mumping sick-room attitude."

But, James now feels compelled to add, such a man does so by an "effort of volition," whereas the Christian saint does so by reason of "the excitement of a higher kind of emotion, in the presence of which no exertion of volition is required." That is why the former's "athletic attitude," even when most "stalwart," almost inevitably breaks down under the crushing weight of life's reversals-and comes to crave the consolations of religion. Urge "personal will and effort" on a person in this plight, and you will be suggesting the "most impossible of things" (pp. 45-46).

In the passages just quoted, James is chiefly preoccupied with contrasting the "moralistic" against the distinctively "religious" type of the strenuous mood. Traces of kinship remain, certainly, but he is deliberately stressing the "added dimension of emotion" which religious feeling comports, especially when one is facing down the evils of human life. His advocacy of religion's "enthusiastic temper of espousal" leads him to contrast it with the way "morality strictly so called can at best but bow its head and acquiesce."

But two observations are in order here: one, on his description of religion; the other, on his characterization of the "moralistic" attitude. In the first place, James is compelled to admit (p. 47n11) that there are people "in whose religious life this rapturousness is lacking": they are religious, but not in "this acutest sense" he wishes to describe "so as to get at [religion's] typical differentia." He has previously admitted (p. 42) that the gradations 
between ordinary and religious types of experience can be so continuous that it becomes difficult to draw any clear, firm line between them. To avoid the methodological difficulties in drawing that line, he has purposely chosen to describe "typical extremes," hence to consider religious experiences which are sufficiently "one-sided, exaggerated, and intense" as to differ unmistakably from non-religious experience.

My second observation is this: in that same zeal for contrast, James has (with the one momentary exception already noted) colored the moralistic attitude in tones that make it more difficult to recognize it as the "strenuous moral mood" of his earlier essays. Now, instead of the militant stride and knight-errant's jocund daring, he stresses the "frosty chill" of Marcus Aurelius' consent to his Logos (p. 42), the stoics's "drab discolored ... resignation," the "dull submission" of the moralist who may "obey" the universal moral law but often "with the heaviest and coldest heart" so that he never feels it as anything other than a "yoke" (pp. 41-44).

\section{More Positive Descriptions of the "Strenuous MooD"}

But despite this somewhat negative characterization, James further on gives several descriptions of one type of saintliness (pp. 211-16) which seem to reinstate the more positive claims he had staked out for the natural strenuous mood in his earlier essays. One such description begins by portraying a certain kind of "character" which constitutes the natural base for any subsequent transformation by religious experience. The diversity of human types, he says, arises chiefly from our "differing susceptibilities of emotional excitement," and the ways in which that emotional excitement can overcome our inhibitions. He proposes the example of a soldier faced with the dangers of battle: some "higher affection," when brought to a certain "pitch of intensity," can wield an 
"expulsive power" over the inhibitions which paralyze him from moving boldly into action, giving him the needed "pitch of courage" to accompany his comrades in their charge. Especially important to the "energetic" type of character he is describing is the "fighting temper," which manifests itself in subtler ways in "earnestness" of character: "Earnestness means willingness to live with energy, though energy bring pain." Now his reference point becomes explicit: "when the strenuous mood is on one, the aim is to break something, no matter whose or what." All obstacles, all psychic counterpulls are "trampled on with a ferocious pleasure the moment they offer themselves as checks to a cause by which our higher indignations are elicited." The counter-appeals of friendships, privileges, possessions suddenly count for nothing; "Rather do we take a stern joy in the stringency and desolation" brought on by renouncing them. "The great thing which the higher excitabilities gives," he adds in a note, "is courage." He then gives a list of "heroes" who had an "inborn genius" for such emotions: there would be many more of them were that inborn gift spread wider.

Now, this is unmistakably the "strenuous mood" of James's earlier essays. As though to remind us that he has been dealing with a pre-religious phenomenon, James proposes to "turn from these psychological generalities," in order to describe the analogous transformation worked by the "new ardor" which supervenes with religious conversion.

He returns to the same topic when setting the scene for his discussion of asceticism (pp. 239-41). Again, he begins on the natural, pre-religious level: we in the West "no longer think we are called on to face physical pain with equanimity," and yet "it is natural and even usual to human nature to court the arduous," for certain human types, at least. For them, "Passive happiness is slack and insipid," and they need a certain dosage of "austerity and wintry negativity, some roughness, danger, stringency and effort" to lend their existence "character and texture and power." Once the dosage is correct for the person 
involved, he "is infallibly aware when he has struck it in the right proportion for him. This, he feels, is my proper vocation, this is the optimum, the law, the life for me to live. . . . here I find the challenge, passion, fight and hardship without which my soul's energy expires." Each individual soul is different, of course; some "are happiest in calm weather" only; but "some need the sense of tension, of strong volition, to make them feel alive and well," or else life's every accomplishment "comes too cheap and has no zest" for them. These, James concludes, are the types of natural character whom religious conversion turns into ascetics.

James's final allusion to the strenuous mood (pp. 28994) occurs when he is endeavoring to overcome whatever residual distaste his hearers might have for asceticism. After all, he argues, asceticism "stands for nothing less than for the essence of the twice-born philosophy" he had earlier described: "the belief that there is an element of real wrongness in the world, which is neither to be ignored nor evaded," but "squarely met and overcome by appeal to the soul's heroic resources, and neutralized and cleansed away by suffering." For life, when all is said, does seem to be a "tragic mystery," in the face of which the "optimism" of the "once-born" type, who manages to "close his eyes" to its "evils" and "sail through life happily on a healthy-minded basis," always seems a "shallow dodge or mean evasion." So "mankind's common instinct for reality" has always thought, and concluded that our world is "essentially a theater for heroism." To this "metaphysical mystery ... recognized by common sense," ascetics, despite their occasional excesses, have always borne witness. Perhaps, James concludes, our modern age, so much more given to softness and effeminacy, could find in a revival of the ascetical ideal a formula for the "strenuous life," the "moral equivalent" we desperately need for that barbaric school of heroism, war.

The Reality of Evil ANd The “Twice-Born"

Central to James's preference for the strenuous mood was his conviction that human experience faced out on a uni- 
verse where evils were real, deep-rooted, and genuinely dangerous. That conviction he articulates nowhere more insistently than in Varieties. So he describes religious happiness (pp. 47-49) as, not a "feeling of escape" from, but a "consent" to evils as exacting "sacrifice." Just as the figure of Satan, or the "negative tragic principle" in reality, adds to the "richness of the picture" Guido Reni painted of the archangel Michael, so the world itself is "all the richer for having a devil in it." Homer's unflinching recognition of life's evils makes his sense of the tragic more clear-eyed than the forced bravado of Whitman's "healthy-minded" optimism (pp. 77-78). In fact, this recognition that evils still remain to be overcome is James's criterion for deeming the "twice-born," the converted "sick-minded" person, as "formally superior" in type to his healthy-minded "once-born" counterpart (p. 138). True it is that individuals vary, so that the "god of battles" may be more appropriate to one, the "god of peace and heaven and home" for another. Granted, it may be extreme for the former type, the "twice-born," to look on the religion of their "healthy-minded" brethren as "mere morality." And yet, James stands to his guns:

the outlook upon life of the twice-born-holding as it does more of the element of evil in the solution-is the wider and completer. The 'heroic' or 'solemn' way in which life comes to them is a 'higher synthesis' into which healthymindedness and morbidness both enter and combine. Evil is not evaded, but sublated in the higher religious cheer of these persons [pp. 384-85, 385n2].

\section{Pragmatism And the Strenuous Mood}

The pages on religion written another five years later for Pragmatism (pp. 139-43) ${ }^{11}$ breathe the same air as James's three latter treatments of the strenuous mood in Varieties: they conjure up, not the world of "wishingcaps" where "every desire is fulfilled instanter," but one that "grows under all sorts of resistances," one of "real adventure" and "risk." It requires a "normally consti- 
tuted" individual with a "healthy-minded bouyancy" to accept its terms. Such a person knows he has "only a fighting chance," and must flail away manfully against "the bewildering accidents of so much finite experience," "Top! und schlag auf schlag!"

The world James's pluralism invites us to accept is one made for the "tough-" rather than for the "tenderminded," so much so that "Many persons would refuse to call the pluralistic scheme religious at all. They would call it moralistic," a world of "self-sufficingness," and reserve the term "religious" for the attitude of "selfsurrender" appropriate to the world of monism. But, he replies, the monist's "religious optimism" may be "too idyllic" over the long run, "too saccharine." There must be some price to be paid in the work of the world's salvation, since the very " "seriousness' that we attribute to life" must mean that "there are genuine sacrifices somewhere, and that something permanently drastic and bitter always remains at the bottom of its cup."

James's option for a "moralistic and epic" kind of universe is rooted, as always, in his conviction that its evils are real and obdurate, that our "really dangerous and adventurous" world encloses "real losses and real losers." Hence anyone who would confront those evils with the requisite "seriousness" (read: in the strenuous mood) must be "willing to pay with his own person, if need be, for the realization of the ideals which he frames."

\section{Conclusion: Deontologism in JAmes}

The "strenuous mood," therefore-and all the stern deontological implications that went with it-occupied a central place in William James's ethical view, and not only for the James who wrote "The Will to Believe," but from beginning to end of his career. For our purposes here, that lifelong ingredience to his thought proves that there was nothing anomalous about its presence in his popular lectures. James's ethic was, to be sure, comprehensive 
enough to embrace eudaemonistic and teleological elements as well; but without his esteem for the battler, the hero, the martyr-without this "deontological streak"James would be unrecognizable.

It was this deontological streak which saved James's "Will to Believe" from becoming a justification for wishful thinking; I have tried to respond here to the doubts which reviewers expressed about whether any such deontological streak existed. I hope I have presented sufficient evidence to show that James's high regard for the strenuous ethical mood clearly qualifies as a strong deontological component in his ethical thinking.

But James esteemed the capacity for, or, better, the preferential lean toward, living in the strenuous mood as so crucial a mark of human excellence that it served to guarantee far more than avoidance of the egoistic life lived in accord with "easy-going" ethical norms. Another service it rendered was that of preventing James's epistemological voluntarism from veering off into willful arbitrariness. To spell out that claim is still another task from the one shouldered here-another task and for another essay.

\section{Notes}

1. See Patrick K. Dooley, in Transactions of the Charles $S$. Peirce Society 21 (1985) 569-76; Shannon McIntyre Jordan, in Review of Metaphysics 40 (1986) 137-38; John J. McDermott, in International Philosophical Quarterly 26 (1986) 189-91; and W. Tilley, in Theological Studies 46 (1985) 755. (I shall refer to these reviews by reviewer's name and page number).

2. (Montreal: McGill-Queens University Press, 1987).

3. See above, p. 121.

4. Dooley, Pragmatism as Humanism: The Philosophy of William James (Chicago:Nelson-Hall, 1974), p. 198n48. I would still strongly question whether MacLeod's article says anything unambiguous about the precise kind of precursive influence I claimed in my study, and would still hold that Edward Madden's remarks in this sense, in his Introduction to Volume VI of the Harvard University Press edition of James's Works 
(1979), while recognizing the difficulties involved in this facet of James's position, fail to show how James deals with them. All citations of James's works are from this series (The Works of William James, ed. Frederick Bowers, 15 vols. in 18 [Cambridge: Harvard University Press, 1975-1988]).

5. Wernham refers to the sixth volume of Works, p. 161; he has chosen well, for pp. 159-61 contain James's distinction (from "The Moral Philosopher and the Moral Life") between the "strenuous" (sometimes called the "serious") and the "genial" or "easy-going" moral moods. Yet, as we shall have occasion to see, James has a good deal more to say on this distinction, some of which raises questions as to the argumentative use Wernham makes of this facet of James's thought.

6. See above, pp. 101-104.

7. Writers on ethics frequently distinguish "teleological" systems (in the sense in which I am here using the term "eudaemonist") from "deontologisms"- as though deontologism were eo ipso non-teleological. This seems to me a confusing classification: for in the subjective meaning of "teleological," one can "act purposively" by adopting as the purpose of one's ethical activity either the eudaemonist's aim of being "better off," or the deontologist's aim of "doing one's duty." The same is true of the objective, metaphysical meaning of the term: one can believe (or claim to know) that reality is structured "teleologically," i.e., so as to require and/or reward certain forms of subjectively purposive behavior, whether that behavior be of the eudaemonist or deontological sort.

8. See "Is Life Worth Living," in Works VI, p. 57.

9. I quote from the version of the "faith-ladder" contained in Some Problems of Philosophy, in Works VII (1979), p. 113.

10. Varieties dates from the years 1901-1902, "The Will to Believe" from 1896.

11. Pragmatism dates from 1906-1907. 